\title{
Harstad injury prevention study: prevention of burns in young children by community based intervention
}

\author{
Børge Ytterstad, Gordon S Smith, Carolyn A Coggan
}

Surgical Department, Harstad Hospital, 9400 Harstad, Norway B Ytterstad

Johns Hopkins University Centre for Injury Research and

Policy, Baltimore, USA G S Smith

Injury Prevention Research Centre, University of Auckland, New Zealand

C A Coggan

Correspondence to: Dr Ytterstad (e-mail: borgey@online.no).

\begin{abstract}
Objective-To describe the long term effectiveness of a community based program targeting prevention of burns in young children.

Design-Quasiexperimental.

Setting-The Norwegian city of Harstad (main intervention), six surrounding municipalities (intervention diffusion), and Trondheim (reference).

Participants-Children under age 5 years in the three study populations.

Methods-Outpatient and inpatient hospital data were coded according to the Nordic system, and collected as part of a national injury surveillance system. Burn data collection started in May 1985 . The first 19.5 months of the study provided baseline data, while the last 10 years involved community based intervention, using a mix of passive and active interventions.

Results-The mean burn injury rate decreased by $51.5 \%$ after the implementation of the intervention in Harstad $(p<0.05)$ and by $40.1 \%$ in the six municipalities (not significant). Rates in the reference city, Trondheim, increased $18.1 \%$ (not significant). In Harstad and the
\end{abstract}

six surrounding municipalities there was a considerable reduction in hospital admissions, operations, and bed days. Interventions with passive strategies were more effective, stove and tap water burns being eliminated in the last four years, while active strategies were less effective.

Conclusions-A program targeting burns in children can be effective and sustainable. Local injury data provided the stimulus for community action.

(Injury Prevention 1998;4:176-180)

Keywords: burns; Harstad injury prevention study

"The toddler pulled down the coffee kettle from the stove and was scalded". This very common emergency room presenting complaint repeats itself as surely as the coffee break. While there are minor variations on this theme, the resulting burns cause considerable morbidity in children. ${ }^{1}$ In a study of children under age 7 in Trondheim, Norway, burns were second only to fractures in requiring hospital care. ${ }^{2}$ Scalds and contact burns are the two most common mechanisms in developed countries ${ }^{3-5}$ with coffee and tea being the most frequent products involved. ${ }^{356}$ In developing countries, cooking fires are the more common source of

Table 1 Interventions classified by Haddon's matrix, strategic models, and applied concepts in social learning (cognitive) theory

\begin{tabular}{|c|c|c|c|c|}
\hline Interventions & $\begin{array}{l}\text { Haddon's matrix, } \\
\text { cell number }(s)^{17}\end{array}$ & Active or passive ${ }^{8}$ & Health education model ${ }^{15}$ & $\begin{array}{l}\text { Concept(s) in social learning } \\
\text { (cognitive) theory }{ }^{16} \text { applied }\end{array}$ \\
\hline Injury prevention group to promote programs in community & All & Active and passive & $\begin{array}{l}\text { Preventive, } \\
\text { radical/political, self } \\
\text { empowerment }\end{array}$ & $\begin{array}{l}\text { Social and physical } \\
\text { environment }\end{array}$ \\
\hline $\begin{array}{l}\text { Relevant local private and public organisations promote child } \\
\text { safety (Red Cross, women's organisations) }\end{array}$ & $1,2,3,5,7$ & Active and passive & All three & Social environment \\
\hline $\begin{array}{l}\text { Media strategy describing local child burn injury problem, } \\
\text { distribution of burn injury data with free texts (table 2) }\end{array}$ & $1,2,3,5,7$ & $\begin{array}{l}\text { Active, may lead to } \\
\text { passive }\end{array}$ & All three & $\begin{array}{l}\text { Expectations and } \\
\text { expectancies }\end{array}$ \\
\hline $\begin{array}{l}\text { Promotion of tap water thermostat setting at } 55^{\circ} \mathrm{C} \text { through } \\
\text { media and individual counseling }\end{array}$ & 2,5 & $\begin{array}{l}\text { Active, may lead to } \\
\text { passive }\end{array}$ & $\begin{array}{l}\text { Preventive, self } \\
\text { empowerment }\end{array}$ & Physical environment \\
\hline $\begin{array}{l}\text { Promotion of the availability of cooker safeguards in stores } \\
\text { selling electric stoves }\end{array}$ & 3 & Passive & $\begin{array}{l}\text { Preventive, self } \\
\text { empowerment }\end{array}$ & Physical environment \\
\hline $\begin{array}{l}\text { Promotion of the purchase and installation of cooker } \\
\text { safeguards in homes }\end{array}$ & 2,5 & $\begin{array}{l}\text { Active, may lead to } \\
\text { passive }\end{array}$ & $\begin{array}{l}\text { Preventive, self } \\
\text { empowerment }\end{array}$ & Physical environment \\
\hline $\begin{array}{l}\text { Promotion of increased parental vigilance in putative burn risk } \\
\text { situations (through items appearing in local media and } \\
\text { parental counseling by public health nurses and doctors) }\end{array}$ & 1 & Active & $\begin{array}{l}\text { Preventive, self } \\
\text { empowerment }\end{array}$ & Behavioral capability \\
\hline $\begin{array}{l}\text { Promotion of parental skills in giving first aid after burns have } \\
\text { occurred (cooling of burned body areas) }\end{array}$ & 7 & Active & Self empowerment & Behavioral capability \\
\hline $\begin{array}{l}\text { Data feedback to parents of small children via media and } \\
\text { health services showing local ability to cope with child burn } \\
\text { injury problem, long term, increasing individual and } \\
\text { community perception of coping skills }\end{array}$ & 4 & Active & Self empowerment & $\begin{array}{l}\text { Self efficacy, positive } \\
\text { reinforcement/reward }\end{array}$ \\
\hline
\end{tabular}


Table 2 Examples of free texts classified by products and mechanism of burn injury. These were extensively used in interventions e.g. by public health nurses in counseling sessions with parents

\begin{tabular}{|c|c|c|}
\hline Burn type & Mechanism & Free text descriptor* \\
\hline \multirow[t]{4}{*}{ Scalds } & Upsetting cups & $\begin{array}{l}\text { Child upset mother's coffee cup, contents spilled over the abdomen } \\
\text { Child crawled up to table, grabbed father's cocoa cup and upset it } \\
\text { Upset coffee cup while sitting in father's lap } \\
\text { Put hand in cup of hot coffee } \\
\text { Sat at kitchen table, grabbed cup of tea, upsetting it } \\
\text { Just started to walk, pulled table cloth, upsetting coffee cup, was scalded }\end{array}$ \\
\hline & Upsetting large receptacles with boiling liquid from cooking stoves & $\begin{array}{l}\text { Pulled down pot with boiling egg water from stove } \\
\text { Pulled down coffee kettle from stove } \\
\text { Played in kitchen, pulled down pot of boiling oatmeal } \\
\text { Climbed chair close to the stove and pulled down coffee kettle }^{\star} \\
\text { Pulled down tea kettle from stove }\end{array}$ \\
\hline & Upsetting large receptacles of hot liquid from other places & $\begin{array}{l}\text { Alone in kitchen, climbed the table and upset full teapot, scalded } \\
\text { Playing in living room, upset coffee pot, scalded } \\
\text { Stood besides living room table, upset pot with hot water } \\
\text { Upset newly boiled cocoa in large pot from table }\end{array}$ \\
\hline & From tap & $\begin{array}{l}\text { Climbed into bathroom sink and was scalded by opening hot water tap } \\
\text { Was scalded from hot water tap in kitchen } \\
\text { Opened hot water tap and was scalded on left side of abdomen } \\
\text { She and her twin sister got into bathroom, was scalded from tap }\end{array}$ \\
\hline \multirow[t]{8}{*}{ Contact burns } & Electrical iron & $\begin{array}{l}\text { Mother was ironing, turned away for a moment, the child overturned the } \\
\text { iron and was burned on hand }\end{array}$ \\
\hline & Electrical stove for cooking & Burned hand on cooker \\
\hline & Electrical stove for heating & Placed hand on stove \\
\hline & & Fell from chair on stove \\
\hline & & Placed both hands on living room stove \\
\hline & & Sat down on stove, burned buttocks ${ }^{\star}$ \\
\hline & Wood or coal burning stove for heating & $\begin{array}{l}\text { Placed both hands on stove, burned both hands } \\
\text { Was burnt on stove }\end{array}$ \\
\hline & & While plaving in the hall, was burnt on stove \\
\hline \multirow[t]{3}{*}{ Open fire } & Matches & Played with matches, pyjamas caught fire ${ }^{\star}$ \\
\hline & & Siblings played with matches, bedclothes caught fire ${ }^{\star}$ \\
\hline & Open fire & While playing in the yard, the child ran into the open fire ${ }^{\star}$ \\
\hline
\end{tabular}

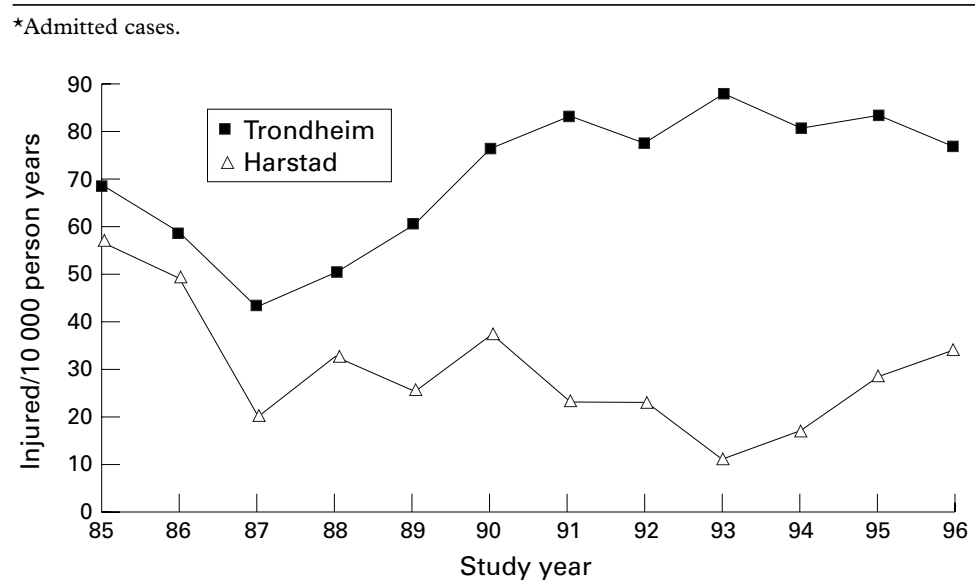

Figure 1 Yearly moving average of child burn injury rates.

burn injuries. While the epidemiological characteristics of burns may vary in different populations, ${ }^{3567}$ universal intervention strategies can be applied.

Interventions against injuries may be classified as active or passive. Active interventions are those that require the consistent active participation of the individual or caregiver. Passive interventions, not requiring this participation, are considered to be more effective than active interventions. ${ }^{8}$ An example of a passive intervention is the lowering of water heater temperature settings to prevent tap water scalds. While some authors have reported increased attention, knowledge, and self reported change in safety practice as a result of active interventions, ${ }^{910}$ few intervention studies have reported any effect on the incidence of burns. ${ }^{511}$ For example, one study showed that public health nurses increased compliance with recommended safety messages but lacked outcome data on burns in the home. ${ }^{12}$ The strength of the present study is that outcome data, in terms of reductions in burns and scalds, are demonstrated.

In a recent review of burn interventions, few studies were cited that demonstrated significant reductions in burn rates from community interventions. ${ }^{13}$ Other studies were highly focused on specific strategies such as changing the temperature for hot water. ${ }^{14}$ Our earlier Harstad study used a mix of active and passive interventions in a broad based community approach and previously reported a significant reduction of burn injury rates in young children. ${ }^{5}$ The aim of the present paper is to report the long term effectiveness and sustainability of this program based on changes in burn injury rates, mechanisms of injury, severity, and short term hospital care costs.

\section{Methods}

The epidemiology of burns among young children was charted in a prospective comprehensive recording system in two hospitals. The intervention (Harstad) and reference city (Trondheim) are geographically isolated by approximately 1000 kilometres. The study lasted 12 years and included children below 5 years of age. During the first 19.5 months both cities were exposed to a national child injury prevention program. During the next 10 years, Harstad (population 23 000) was, in addition, exposed to a community based intervention using local data for event analysis, planning of interventions, and motivation for long term continuation of the program. During this decade, six municipalities surrounding Harstad (population 14 000) were increasingly exposed to the same interventions. We therefore examined data on outpatient treatment and admissions from these six adjacent municipalities in 
Table 3 Changes in burn rates (per 10000 person years) in three populations of children 0-4 years old

\begin{tabular}{|c|c|c|c|c|c|c|c|c|c|}
\hline & \multicolumn{3}{|c|}{ Baseline * } & \multicolumn{3}{|c|}{ Interventiont } & \multirow[b]{2}{*}{ Relative risk } & \multirow[b]{2}{*}{$\chi$} & \multirow[b]{2}{*}{$p$ Value } \\
\hline & No & Person years & Rate & No & Person years & Rate & & & \\
\hline Harstad & 12 & 2292 & 52.4 & 42 & 16546 & 25.4 & 0.49 & 4.19 & 0.04 \\
\hline Trondheim & 76 & 12281 & 61.9 & 700 & 95789 & 73.1 & 1.18 & 1.73 & 0.19 \\
\hline Six municipalities & 4 & 1525 & 26.2 & 13 & 8266 & 15.7 & 0.60 & 0.32 & $0.32 \ddagger$ \\
\hline
\end{tabular}

${ }^{\star}$ Baseline was 18 months for Trondheim and 19.5 months for Harstad and the six municipalities. $\dagger$ Intervention lasted 10 years.

$\ddagger$ Two tailed $\mathrm{p}$ value by Fisher's exact test.

order to determine if there was diffusion of the intervention to these areas. Trondheim (population 134000 ) served as a control or comparison site. Harstad and Trondheim, while different in size, are of similar demographic comparison with regard to age structure of the population, income levels, employment base, and other socioeconomic factors.

INTERVENTIONS

Both passive and active interventions were promoted. Passive interventions included: (i) the purchase and installation of cooker safeguards (guard rail around the edge of the stove); (ii) lowering tap water thermostat settings to $55^{\circ} \mathrm{C}$ in homes, kindergartens, and public buildings. Active intervention were based on health education models ${ }^{15}$ and Bandura's social learning theory. ${ }^{16}$ The interventions were classified according to Haddon's matrix $^{17}$ and have been previously documented. ${ }^{5}$ Briefly this involved taking a broad public health approach. A cross sectorial injury prevention group was formed in 1986 . Cooperation partners were invited according to the previously described local epidemiological pattern of burns. ${ }^{5}$ Because most burns occurred in children under 5 years of age, ${ }^{5}$ the cooperation of the public health nurse corps was essential. Opportunities for parental counseling by public health nurses commenced during home assessments two weeks before birth and at vaccination time, thus providing parental and child contact every four months for four years. Because almost all Norwegian children are vaccinated by public health nurses, a good program reach was assured.

Lowering of tap water temperature and availability and use of cooker safeguards was promoted by media, the author (being responsible for surgical treatment of burned children), and the public health nurses. The latter went to the electrical appliance stores to promote cooker safeguard availability. To promote sustainability of the program there were regular press releases on the progress of the intervention. A high awareness on safety issues existed in the community because of the ongoing Harstad World Health Organisation

Table 4 Number of burns in children 0-4 years old from Harstad and the six municipalities by mechanism/product involved and three four year periods *

\begin{tabular}{lcll}
\hline & $\begin{array}{c}\text { Period 1 } \\
85-88\end{array}$ & $\begin{array}{l}\text { Period 2 } \\
89-92\end{array}$ & $\begin{array}{l}\text { Period 3 } \\
93-96\end{array}$ \\
\hline Contact with hot surface & 5 & 9 & 9 \\
Cups and receptacles overturned from tables & 12 & 9 & 6 \\
Receptacles pulled down from stoves & 5 & 3 & 0 \\
Tap water scalding & 3 & 2 & 0 \\
Not classifiable & 6 & 0 & 2
\end{tabular}

^Each period contains approximately the same number of person years.
Safe Communities program which targeted other injury prevention issues as well. The specific interventions are outlined and classified in table 1 according to their theoretical and conceptual implications.

Table 2 demonstrates how small anecdotes about local injuries were used in parental counseling sessions by public health nurses and doctors. The information in this table was used to (i) promote increased parental vigilance, (ii) motivate parents and plumbers to set thermostats to $55^{\circ} \mathrm{C}$, and (iii) to promote availability and installation of cooker safeguards. The analysis and promotion of this "free text" was an essential part of the whole intervention program (descriptions of injury circumstances).

\section{DATA ANALYSIS}

The Epi-Info program (5.01) was used for analysis and data entry. ${ }^{18}$ For $\chi^{2}$ tests, $\mathrm{p}$ values below 0.05 were regarded as significant in statistical testing.

\section{Results}

CHANGES IN BURN INJURY RATES

From period one to period two burn injury rates decreased $51.5 \%$ in Harstad $(p<0.05)$ and $40.1 \%$ in the six municipalities (not significant). The corresponding rates in Trondheim increased $18.1 \%$ (not significant; table 3). The yearly moving average of child burn injury rates for Harstad and Trondheim is illustrated in fig 1 .

CHANGES IN BURN SEVERITY AND MECHANISM Not only have burn rates come down in the intervention community but there has been a shift from the more severe stove and tap water scalds towards less severe contact injuries (table 4). The rates continued to decline to zero for the last four years of the intervention period for the stove and tap water scalds (the most serious ones), while the changes in cups and contact burns appear to have been less dramatic.

Unfortunately the "free text" information available from Trondheim was incomplete, and so it was not possible to examine changes in the patterns of burns in the control city.

CHANGES IN SHORT TERM HOSPITALISATION COSTS Data taken from hospital records showed a considerable reduction in admissions of burn cases, number of surgical procedures requiring general anaesthesia, and hospital bed days. These results have previously been reported. ${ }^{5}$ No children under 5 from the intervention populations were admitted for burns during the last three years of the study reflecting the 


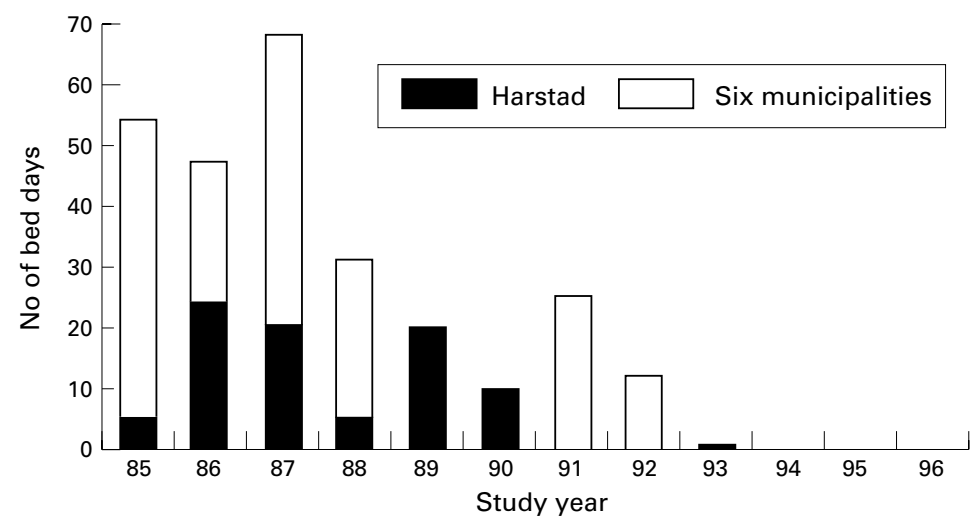

Figure 2 Yearly bed day expenditure.

decrease in burn severity as previously described. For example, during the last six years of the study no surgical procedures requiring general anesthesia were performed on children under 5 from the Harstad population. The yearly bed day expenditure for the two intervention populations are shown in fig 2 . Similar information was not available for the reference community of Trondheim.

\section{Discussion}

Findings from the present study suggest that the interventions adopted were effective in preventing the most serious burns resulting from stove and tap injuries. These may have been prevented because they relied upon passive measures, such as installing cooker safeguards, and lowering tap water temperature. However, to support this claim, information on program reach is required. A weakness of this study is the lack of process evaluation information. We do not know if there were increases in cooker safeguard installation or tap water temperature reductions. The lack of systematic repetitive home assessments was due to insufficient resources. From anecdotal reports based on discussions with parents and public health nurses there is, however, reason to believe that these protective measures increased with time in Harstad. Certainly the injuries preventable by these strategies have been reduced. The strong sense of community empowerment that developed during the program may have enhanced compliance with the recommended safety measures.

The active part of our interventions (for example, media campaign, counseling sessions) was aimed at increasing parental vigilance during food preparation and consumption (for example, coffee drinking). This component was considered important due to the number of serious injuries resulting from the overturning of receptacles of hot liquids. Findings from this study may indicate that some success was achieved even for this type of active intervention (tables 2 and 4). However, the results were less dramatic than for the more serious burns preventable by cooker safeguards and lowering of tap water temperatures.

This program was initially directed at the cause of all burns. As shown it had minimal impact on the minor burns. These minor burns seem to be difficult to prevent. In addition, young children may develop protective actions through recovery from a minor injury incident, such as a small burn. This area is controversial and has not been well studied. The real issue now is to develop effective means of preventing serious burns such as those arising from excessively hot tap water and unprotected pots on stoves.

In addition to reduced human suffering, the hospital data also showed reduced inpatient care days (fig 2). Although numerically few, children suffering from burns who are in need of hospital admission comprise a patient group who often require considerable resources through repeated grafting procedures, hygienic precautions, treatment of infections, and supportive care to patients and parents. The direct cost of hospital inpatient care for burns is reported to be similar to those in a surgical intensive care unit, that is, US $\$ 1296$ per day in $1986 .{ }^{19}$ We assume that intervention diffusion caused the burn rate reduction in the six municipalities because: (i) intervention items occurred in local media also covering these six municipalities; (ii) members of participating organisations and health service professionals in Harstad communicated with colleagues in the six municipalities; and (iii) the availability of safety equipment - for example cooker safeguards also increased for out-of-town people shopping in Harstad. Having made this assumption, a saving of 490 bed days may be calculated by subtracting observed bed day expenditure for the last decade of the study from expected (extrapolated from baseline). Bearing in mind that hospital cost from injuries may be only $23 \%$ of total economic costs, ${ }^{20}$ the potential for savings on a national scale is great.

Our study demonstrated that a prevention program for burns in young children can be effective and sustainable, by using high quality local injury data to (i) target and model a community based injury prevention, and (ii) evaluate the outcome. It suggests that the promotion of passive interventions had greater effects on burns than active interventions. Programs such as ours have a great potential for reducing human suffering and saving short term hospital costs.

We thank the Norwegian Research Council for Science and Humanities for financing the evaluation of the project, the Norwegian National Institute for Public Health and Arve Sjollingstad for national injury data, and public health nurse Solveig Rostol Bakken and her colleagues in the Harstad public nurse corps for their major contribution to child safety. The assistance of the Injury Prevention Research Centre, University of Auckland (particularly researcher Virginia Fairnie) and the Johns Hopkins Center for Injury Research and Policy is also acknowledged.

1 Baker SP, O’Neill B, Karpf RS. Burn and fire deaths. The injury fact book. Lexington, MA: Lexington Books, 1984: $139-54$

2 Sahlin Y. Injury registration. A tool for accident preventive work. Trondheim, Norway: Tapir, 1990. (Thesis.)

3 Lyngdorf P. Epidemiology of scalds in small children. Burns 1986;12:250-3.

4 van Rijn O J L, Grol MEC, Bouter LM, et al. Incidence of medically treated burns in the Netherlands. Burns 1991;17: 357-62.

5 Ytterstad B, Søgaard AJ. The Harstad injury prevention study: prevention of burns in small children by communitystudy: prevention of burns in small children by

6 Phillips W, Mahairas E, Hunt D, et al. The epidemiology of childhood scalds in Brisbane. Burns 1986;12:343-50. 
7 Forjouh SN, Guyer B, Smith GS. Childhood burns in Ghana: epidemiological characteristics and home-based treatment. Burns 1995;21:24-8.

8 Robertson LS. Injuries: causes, control strategies, and public policy. Lexington, MA: Lexington Books, 1984.

9 Lindblad BE, Terkelsen CJ. Domestic burns among children. Burns 1990;16:254-6.

10 Erdmann TC, Feldman KW, Rivara FP, et al. Tap water burn prevention: the effect of legislation. Pediatrics burn prevention:

11 Glent-Madsen L, Nielsen TG. Epidemiology of burns. A follow-up from a 20-year period at Odense hospital. Ugeskr Laeger 1990;152:2997-9.

12 Sullivan M, Cole B, Lie L, et al. Reducing child hazards in the home. A joint venture in injury control. F Burn Care Rehabil 1990;1:175-9.

13 Harborview Medical Center. Injury prevention and Research Center. Systematic Reviews of Childhood Injury Prevention Interventions. Http://weber.u.washington.edu/ hiprc/childinjury/ (20 July 1997).
14 Webne S, Kaplan BJ, Shaw M. Pediatric burn prevention: an evaluation of the efficacy of a strategy to reduce tap water evaluation of the efficacy of a strategy to reduce tap water temperature in a popula

15 Tones K, Tilford S, Robinson Y. Health education. London: Chapman and Hall, 1990.

16 Bandura A. Social foundations of thought and action: a social cognitive theory. New Jersey: Prentice-Hall, 1986.

17 Haddon W. Conference on the prevention of motor vehicle crash injury, 10 January 1979 . Ben-Gurion University of the Negev Beersheba. Isr f Med Sci 1980;16:45-65.

18 Dean AG, Dean JA, Burton AH, et al. Epi-Info, version 5: a word processing, database, and statistics program for epidemiology on microcomputers. Stone Mountain, GA: Centers for Disease Control and Prevention, 1990.

19 Munster AM, Smith-Meek M, Sharkey P. The effect of early surgical intervention on mortality and cost-effectiveness in surgical intervention on mortality and cost-
burn care, 1974-91. Burns 1994;20:61-4.

20 Lindqvist K. Towards community-based injury prevention. The Motala model. Linkøping, Sweden: Linkøping University, 1993. (Thesis.)

\section{Thoughts from Southern Africa}

What are the elements which are truly indispensable to the philosophy and practice of child safety? Research? Academic debate? Funding, perhaps? If our window on the world is framed by a higher education in health related disciplines, the contents of peer review journals, the occasional scientific meeting and an unfailing adherence to Haddon's matrix, then the above mentioned elements will most probably rate highly among our list of priorities. If so, we may be guilty of two assumptions - firstly, that academic health care is immortal, and secondly, that the concept and practice of injury prevention will survive as long as the towers of learning remain intact. In Africa today, both assumptions are groundless.

With utmost respect to the wide spectrum of disciplines that contribute to the promulgation and execution of safety programmes throughout the world, it is more than coincidence that many of the pioneers in this field were (some still are) prominent figures in clinical medicine: Hugh Jackson, Alastair McKellar, Sid Cywes, and J Alex Haller are just some who immediately come to mind. Clinicians faced with the unpleasant duty of dealing with the casualties of an unsafe society will predictably strive for a change to the status quo, as the four personalities quoted above did with distinction. In the developed world, there are many committed health care professionals who have followed and will follow this path with the necessary zeal and selflessness (because child safety offers unique rewards, but it certainly does not pay the rent!). In Africa, the changing pattern of medical training and practice as well as the collapse of vital infrastructures (law enforcement and municipal services in particular) are unlikely to foster such enthusiasm for injury prevention when the energy required on the one hand, and the financial rewards on the other, are vastly disproportional to one another.

It is sad to think that the survival of injury prevention on the African continent may soon depend on it being adopted by one of those agencies based in the First World, but for the efforts of whom vaccination programmes, food relief, and basic health education would also be non-existent.

DAVID BASS

Department of Paediatric Surgery, Red Cross War Memorial Children's Hospital,

Rondebosch 7700, South Africa (Tel: +27-21-658 5199, fax: +27-21-689 1287, e-mail:daveb@redxch.wcape.gov.za) 